Vols. LXV-LXVI, January-June, July-December, 2019

ISSN 1607-2278 (Print), DOI : https://doi.org/10.3329/pp.v63i1-2.55960

\section{SOCIAL NORMS, CULTURAL RITUALS AND MORAL BAGGAGE: CONTRASTING REALITIES FOR WOMEN IN SUNIL GANGOPADHYAY'S SHEI SHOMOE}

\section{Fairooz Jahan*}

\begin{abstract}
The relationship between history and literature is inseparable from the point of view that both disciplines deal with the whole spectrum of human experience. History shapes many a form of literature. Many of the world's most celebrated novelists have based their storyline on historical facts. Conversely, historical accounts are known to have been complimented by literary sources. More often than not, womens' historians have to rely on literature when no other sources exist to reconstruct the life of women in a given time frame. Shei Shomoe (Those Days) is one such historical novel by Sunil Gangopadhyay where he captured a vivid picture of the cross currants of social, political and intellectual life in the city of Kolkata in the nineteenth century. The time-frame of the novel is from 1840 to 1870 and that is the time when the Woman's Question came to the forefront as a major factor in the discourse on social reform. Sunil Gangopadhyay, in his groundbreaking novel, adds to this discourse with his rare
\end{abstract}

* Lecturer, Department of History, University of Dhaka Email: fjahan2811@gmail.com insight into the lives of women from varied social and class backgrounds to see how they negotiated patriarchal attitudes and defined their own space. This paper is a tribute to Sunil Gangopadhyay's efforts to explain the dichotomous relationship between patriarchy and social reform and how womens' lives got caught in the middle.

\section{Introduction}

Allan H. Pasco in his article 'Literature as Historical Archivec stated that while literary works would not normally provide exact information about speeches, laws, wars etc they would serve particularly well to depict everyday life in the streets, in houses, apartments, and hovels, an overall picture of the society. ${ }^{1}$ This statement is true for the novel in question as it shows a genuine picture of the society of Kolkata through an imaginative saga of the Singha and Mukherjee families along with addressing many other aspects. The narrative is also dotted with real life characters which had a prominent social presence during the time frame of the novel. Nineteenth century Bengal witnessed large scale changes in social, psychological, intellectual and cultural areas as a result of the contact between certain sympathetic British and Hindu intelligentsia. ${ }^{2}$ This connection resulted in a series of social reform movements which addressed predominantly the Woman's Question. While talking about social reforms for the development of women in nineteenth century, one person who deserves utmost respect is Raja Ram Mohan Roy. The great reformer Raja Ram Mohan Roy, along with his multidimensional reform activities, focused on the miseries suffered by women of then society and strongly denounced the ongoing unjust customs for women. He established Brahma Shabha in 1828 and had relentlessly worked to breakdown the shackles of 
caste system, advocated female education and female property right and fought child marriage and polygamy. The most significant measure by Raja Ram Mohan Roy for the sake of Bengal's women was his effort in abolishing Satidah ${ }^{3}$ system in 1829. Raja Ram Mohan Roy has expressed his views on women in five pamphlets, two petitions and a number of personal letters. His efforts helped women to come out of the funeral pyre of their husbands and eventually to come out of the andarmahal too. Like his European counterparts, Ram Mohan Roy was concerned with the oppression of women, their economic dependence and their struggle to selfhood. ${ }^{4}$ If Raja Ram Mohan Roy played the role of the first humanist pandit in Bengal, Ishwar Chandra Vidyasagar was the second. Whether the former for Satidah abolition, the latter was for child widow remarriage along with many other reforms. ${ }^{5}$ Though by Ram Mohan Roy's heroic efforts, widows were saved to live but that life was full of unimaginable hardship. They were strictly denied access to almost everything. They had to follow very strict customs and also were put on strict diet aimed at robbing them of their youth, beauty and sexual desire. ${ }^{6}$ Legendary social reformer Ishwar Chandra Vidyasagar played a crucial role in introducing widow remarriage in Bengal and also fought for women's education as well as ending the shameful practice of child marriage. His efforts to bring development for the women in the society and the promulgation of the Hindu Widow's Remarriage Act in 1856 have been shown in Sei Somoy in details and thus these have been discussed in length in the article's narrative portion. But not everyone was in support of these reform measures. There were serious debates among men on matters such as education of women, child marriage, widow remarriage, status of women and so on. The opposition encountered by Viddyasagar during his lifetime both from the Bengali midddleclass as well as a prominent figures such as Bankim Chandra Chattopadddhyay speaks volumes. ${ }^{7}$

Thus, Sumanta Banerjee, along with the 'White Man's Burden' in colonial Bengal there was the 'men's burden' on the shoulder of the colonial ruler and native 'Bhadralok' to emancipate native women from ignorance. ${ }^{8}$ But no one noticed that the bulk of women themselves were very unaware of the ongoing reforms and were not directly associated with it. Urban illiterate women married to educated men were still living in the same bubble of previous centuries, puzzled by the sudden demands of changes from their elite intellectual partners which caused more miseries for them and often widened the emotional gap with their husbands. The female characters of Sunil Gangopadhyay's Shei Shomoe have been developed based on that social environment of Bengal. The novelist introduces us to an array of female protagonists: Bindu, a child widow who ends up at a brothel in Varanasi; the languorous beauty Kamala Sundari and Hira Bulbul who were not only prostitutes, but also artists in their own right; Bimbabati, ginni $i^{9}$ of a typical elite household of Kolkata; obese Thako, whose fate turned her from a rural housewife to a maid in a zamindar household of Kolkata; Kushumkumari, a classic example of widow remarriage in upper class household and so forth. The author has captured the picture of the nineteenth century Bengali society through these fictional women who were still on the suffering end despite being the central object of the reform movements. According to the translator of Shei Shomoe, Aruna Chakravarti, the characters, historical and fictional, are flesh and blood human beings, caught between two worlds--one old, decrepit and dying by degrees and the other struggling to be born. 


\section{Methodology}

Research for the paper has been conducted taking the novel itself as primary source. The translated version of the novel Those Days has also been studied well. To ensure authenticity of facts stated in the novel, primary sources like census reports, newspapers, statistical accounts on nineteenth century Bengal, and relevant online journal articles have been used in addition to the main novel.

\section{The Narrative}

The sharp division between the public and private spheres of life was most acutely felt in the growing urban culture of nineteenth century Kolkata. According to a Young Bengal ${ }^{10}$ Radical of 1856, "Woman has but one source- Home. The end and aim of her life is to cultivate the domestic affections, to minister to the comfort and happiness of her husband, to look after and tend her children, and exercise her little supervision over domestic economies." 11 The statement fits the role of women in the upper class families depicted in Sunil's novel. The life of these women revolved around filial relationships and domestic responsibilities. The observance of strict purdah (seclusion for women) completely disconnected the women of elite households from the outer world. These women seldom came out of the andarmahals (inner quarters of a household where women lived) and whenever they did, they used covered palanquins. We see Bimbabati of the Singha house coming to the Ganga ghat (river bank) for her ritual bath. People around the area recognized the palanquin from its crest and moved respectfully. The bearers then stepped into the water and dipped the palanquin, with Bimbabati in it, seven times. James Kerr, in describing the elite women of Bengal has mentioned about this strong purdah system just as Sunil has portrayed. Kerr stated that the elite women were of fairer complexion and had more delicate features than the lower ranking women and like nuns they were protected by stone walls from the evil world. ${ }^{12}$ Though they were nearly invisible to the outer world, these women were the heads of the household and were in charge of overall indoor management. ${ }^{13}$ Their duties passed on to the next generation of women after their death. In Mukhopadhyay's family after the death of Soudamini, the widowed daughter Narayani became the head of the household. After Bimbabati, her daughters-in-law took her position. They had the overall command in the andarmahal. The families were generally joint families with several generations of women living together and the maintenance of the household peace depended on the harmony among the myriad of near and distant relatives living under one roof. We see a lot of women, both sheltered and related, living together as in the Singha household, but they were ruled by the ginni or the mistress of the house who was either the senior most female member of the family, or, the wife of the head male of the house. The ginni sometimes had economic control as well in absence of her husband. Bimbabati acquired the power to take decisions regarding finance after the death of Ramkamal Singha. So the author did not show these women as completely vulnerable. They had power to exercise inside the andarmahal. Apart from managing household, the andarmahal women had sources of recreations as well. On occasions, vendor women came into the andarmahal to sell clothing items and jewellery. ${ }^{14}$ Sunil did not write much about the women from the lower strata of the society except for the dasi (domestic workers) in zamindar families. There were a series of domestic workers for specific household works. In the Singha family, there were a total of 
eighteen servants and the majority of them were female. A dasi very close to Bimbabati was Chintamani who was also a nanny for Nabinkumar. These working women of lower ranks who came from the world outside and had access to the andarmahal were, more often than not, the only sources for the elite women to know about outer world. ${ }^{15}$ Occasionally the young brides could come out of the four walls of the andarmahals to travel to their friends' houses who were also brides of other zamindar houses. In Shei Shomoe we see Nabinkumar met Kusumkumari, the daughter-in-law of Hatkhola zamindar house who was sent by her mother-in-law in a palanquin to Singha house to play with Krishna Bhamini, first wife of Nabinkumar. Another occasion on which these women could come out of their houses was when different plays were arranged in some zamindar houses where women attended under strict purdah. Besides these, they occasionally travelled to their paternal house. Though these women had great economic affluence through their rich husbands and occasional leisure too, they suffered a lot due to their husbands' affairs. Sunil described andarmahal womens' deplorable condition through words like- "A man's enjoyment of other women lacked spice and wasn't quite complete if he didn't have a wife weeping and tearing her hair in the zenana". ${ }^{16}$ (Those Days, 350) Ramkamal Singh hardly lived in his house with his wife Bimbabati. He was used to changing mistresses every three years and always picked 'dark skinned girls' like Kamala Sundari. Chandika Prasad, one of the elites of Hatkhola was always into other women and alcohol. But most of the women suffered silently. Women from middle class families were in conditions no worse than that of the elite women. Many of them could not afford coming to Kolkata with their working husbands and were left in the native villages. We see the case of Ambikacharan in the novel, how, due to the high inflation and dense population of Kolkata, he could not bring his wife with him and was living in a hostel. When these husbands came home, there was again a long wait till nightfall as we find in Ishwar Chandra's household where his wife was not allowed to see him in daylight owing to social custom. Those women who did accompany their husbands to the city often had to face severe difficulties to manage the household with a very limited income. In wealthy houses one would pass through court after court to reach the inner household. In a less wealthy family, sometimes it would be just "one small room, no windows for ventilation." 17

The common thing between all these classes of the women of nineteenth century was the tender age at which these women were married. Thus Sunil has shown a number of child brides in the novel. In Hindu upper caste families, the girl child had to get married by the age of eight or at any rate, before the onset of puberty to maintain the caste purity. Child brides of Shei Shomoe are Leelavati, Krishna Bhamini, Sarojini of the Singha family; the daughters of Bidhushekhar Narayani, Bindu, Suhasini, Kundamala; Dulal's wife Subala and so on. Through them, Sunil has shown a gradual transformation of a child bride into a full grown woman of the andarmahal. Though these women were married at a very early age, they often stayed at their paternal house for a few years more until they reached puberty. Kundamala, a daughter of the Mukhopadhyay family, though was married at an early age, finally started her 'zamindar-ginni' life at the age of twelve. Leelavati, first wife of Ganganarayan was in her parental house. We see how Leelavati's parents sent tatya (gifts) to Ganganarayan's house as a reminder to take Leelavati with him as she had reached the 
age to start her life as a wife. And in some cases the child brides used to stay with their mothers-in-law or other women of the house until she was a bit grown. Here Sarojini, second wife of Nabinkumar is an example. From the very beginning, these young brides would be taught to perform the domestic tasks and religious rituals which constituted the daily routine of the andarmahal. ${ }^{18}$ JasodharaBagchi in her article stated that on the fragile shoulders of the child bride laid the burden of keeping the patriarchal structure of the caste Hindu family in place. ${ }^{19}$ Many of these child brides never lived up to the expectations of their husbands who were mostly Englisheducated men imbibed in western cultural values. The sharp contrast between the mentally stymied wives who kept themselves steeped in traditional domesticity and religious rituals and the modernized husbands who were in contact with the white ruling class and other native intellectuals created a wall in their relationships. This was visible in the case of Ganganarayan and Leelavati, and Nabinkumar and Sarojini. Leelavati could never understand the emotional bond which Ganganarayan wanted from his wife. Nabinkumar also could never find the emotional connection with his wife Sarojini as her world was very small compared to that of Nabinkumar. We even see the reluctance to marry such young girls among the emerging educated youth of Kolkata. Madhusudan Datta was annoyed with his father Rajnarayan Datta in the novel because he wanted him to marry a very young girl whom Madhu termed 'a pulling infant, seven or eight years old'. But the efforts of a small number of young English educated men about not marrying a child had no significant impact as the system was smoothly in practice throughout the century and even after that. $^{20}$
Another thing which was in practice for quite a long time in Bengal society was polygamy. In the novel this evil practice has come up again and again. Polygamy was in practice for many reasons among the people of upper caste and one main reason was the obsession to have a male child. The author has shown how angry Rajnarayan Datta kept on marrying one after another in the hope of getting a male successor to perform his death rituals mukhagni ${ }^{21}$ after Madhu left and became a Christian. According to the Census of 1891, one of the major duties of a wife was to produce a son to perform the funeral rituals of her husband. ${ }^{22}$ The other reason shown by the author was the death of the wives. Both the daughters-in-law of the Singha family Leelavati and Krishna Bhamini died at an early age and were replaced by Kushumkumai and Sarojini respectively. Bimbabati herself was the third wife of Ramkamal Singh. The other two wives were Lakhshmimoni and Hembala whom he remembered very faintly. Kundamala, daughter of the Mukhopadhyay's had the same fate. One very important custom of polygamy was prevalent among the Kulin $^{23}$ Brahmans. To be connected by marriage with these Brahmans of aristocratic and noble descent was considered to elevate the dignity of any family. ${ }^{24}$ Marriage became a profession for men belonging to a Kulin family of Brahman caste. A hefty dowry was provided to the bridegroom who in most of the cases already had other wives. L.S.S O'Malley wrote about a Kulin family which had eighteen female relatives married to one ten year old boy. ${ }^{25}$ Sunil Gangopadhyay has attacked the core of this age old custom by showing the character of old, feeble and almost blind Kalikanta Chattopadhyay who was a bhangakulin ${ }^{26}$ and main source of income was the money he collected from regular visits to the parental homes of his wives. Sunil condemned Kulinism 
through the character of Iswar Chandra Vidyasagar who was a student of Kalikanta but decided to cut all ties with him for his heinous practice. But he did not forget to show the other side of the coin too. The novel showed Kalikanta explaining to Ishwar Chandra that how the father of the girl had been begging him to help them out as it was not easy to keep a girl passed her marriage age in house. While describing these malpractices of the society of nineteenth century Bengal, the author has also hinted towards the new changes which were being ushered in. Bidhusekhar being a Kulin Brahman denied his privilege of polygamy even though he did not have a male heir. The new generation of educated males began to discourage this age old malpractice. We see Ishwar Chandra Vidyasagar rebuking Nabinkumar for his desire to marry Kusumkumari despite having a wife and in return Nabinkumar promising Ishwar Chandra to never marry again in his life. Rather, the Westerneducated males began to encourage the idea of having an educated wife with whom they could enjoy a companionate marriage. The perception of the wife as a companion rather than a vehicle of procreation and reproduction took place. ${ }^{27}$ Portraying this fact, the author showed how Madhusudan Datta denied marrying a Hindu girl, as she was not educated and how Ganganarayan was attracted to Bindubashini as Bindu had lot more to offer apart from her womanhood. Rejected by Bindu, Ganganarayan attempted to educate his wife Leelavati by employing a European governess for her. "Education would improve her mental powers and she might in time, come to be a true wife- a wife he could respect and love." (Those Days, 204) The project, however, resulted in utter failure. Leelavati strongly believed, as was the tradition, that merely touching the book could cause her husband to die!
Though the traditional and rigid mindset of women could be partially blamed for their back foot in education, the efforts from the male family members were not genuine enough and were drawn from their own interests of gaining social acceptance among elite peers or keeping options open for their estates to be managed in case of absence of son. Thus, along with Leelavati, the author has depicted the character of Bindubashini, a child widow of nine and half years old who had found utter happiness in education. She was a great learner of Sanskrit and Bengali, even better than her friend Ganganarayan, with whom she used to get lessons from Shibram Acharya. But once she turned fifteen, her classes were discontinued by her father. Soon her books and manuscripts were taken away, leaving her dazed and bereft. The psychology behind the attempts to introduce the females to education and limiting it to a certain level by the nineteenth century men has been explained by Meredith Borthwick while discussing about the report of William Adam's "Report on the State of the Education in Bengal for 1836". Whereas education for males was directly related to the pursuit of employment, female education had no economic function. Rather, an educated girl would become a liability to her parents. The cost of female education in terms of fees, material, so on and the lack of visible pecuniary return were strong economic deterrents in this case. ${ }^{28}$ Literacy was suspected of diverting women's attention from their domestic duties. It would apparently cause a temporary loss of one helper in the household and their unpaid labour. ${ }^{29}$ It was also based on a fear of the unknown powers education could give a woman and a husband's control over an educated woman was less secure. ${ }^{30}$ According to Judith E. Walsh, education in some way cultivated disassociation from the identity of the male member, a sense of 'self'. These factors 
can explain the author's portrayal of the male characters of Shei Shomoe who were associated with female education. The author has described the confused and baffled male society through one single character of Jagmohan Sarkar of Simulia who switched from an earnest spokesman of female education to a rabid Hindu fundamentalist against the same reform throughout the novel.

Similar to education, reforms in the sector of child marriage and polygamy were too little. Though the author showed individuals like Nabinkumar taking stand against it, in mass level it was still in practice. The evils of child marriage and polygamy had another disastrous consequence, the child widow. As a man could marry as many times as he wanted and at any age, there was often huge age difference between the wife and the husband. According to the census report of 1881, this discrepancy of age between husband and wife created many widows. ${ }^{31}$ Many girls used to lose their husband even before starting conjugal life. The life of a child widow was miserable. The widow was considered sacred and her whole life was dedicated to the God with strict customs and regulations. The author showed the miseries of a widow through the character of Bindubashini. The nine and half year old widow had her coarse white than (the 12 yards of cloth that made a saree) wrapped clumsily around her, she sat for hours with closed eyes before the image of the deity Janardan but before she knew it she fell asleep, curled up on the grass mat. This was a common scenario of Bengal. Almost every household had widows maintaining a purposeless life, without any escape. Even the intellectual reformers, when thinking about female emancipation, did not consider the widows as it could have attacked the religious sentiment of the people.
Characters like Jagmohan Sarkar, who was initially an advocate of female education rejected the question of widow remarriage and termed it as a sin to think about such a thing. On his denial the British patron David Hare stated, "Let us forget about widows for the present." (Those Days, 85) But they were not completely forgotten. 'Young Bengal' had been advocating for widow remarriage for a long time. The novel holds great factual discussion on widow remarriage. We see intellectuals like Ramgopal Ghosh, Peary Chand Mitra, Radhakanta Dev in an evening gathering, discussing the condition of child widows and the prospects of their remarriage. But the only way to make that happen was conversion to Christianity as widow remarriage among Hindus was an absurd idea. The person who came to the rescue was Ishwar Chandra Vidyasagar and the author did justice to the historical basis of the novel by giving detailed information of Vidyasagar's efforts. After hearing repeated cases of child widows in his village Birsingha, Vidyasagar decided to look into Hindu religious scripture to find a way to legitimize widow remarriage. He knew that the only way to convince the British colonial government to give it a legal basis was to prove it legal in Hindu religious scriptures as the colonial government would not hurt religious sentiment of the Hindus for fear of disrupting the peace. After vigorous study, Vidyasagar came up with his book, A Discourse on the Necessity of Introducing Widow Remarriage in Society and many articles about the legal basis of widow remarriage from ancient Hindu texts. Vidyasagar got support from the Brahmos and 'Young Bengal' pupils and thousands of women. Some women of zamindar families began to write to him describing their grievances. Many folksongs were made praising Vidyasagar, sung by women. 
One goes like-

Oreh Vidyasagar dibey biye

Tara ar phelbe na chul

Bandhbe beni gunjbe re phul

Sankha sari porbe notun kore. ${ }^{32}$

[Translated in English, the verses mean: Vidyasagar will arrange marriages, so girls don't have to shave their heads. They will braid their hair and adorn it with flowers. They will wear the shakha ${ }^{33}$ and coloured sarees again.]

With evidence from ancient scriptures, Vidyasagar finally put up a petition signed by many prominent people to the government. This antagonized another reformer Radhakanta Dev who did not accept the alien government's interference in Hindu custom and put up another petition with thirty-three thousand signatures protesting widow remarriage. Government supported Ishwar Chandra and passed Widow Remarriage Act (enacted on 26 July, 1856) and in 1874 the Right to Property gave widows a stake in her late husband's property. ${ }^{34}$ Sunil Gangopadhyay's unbiased pen did not skip the problems associated with this Act. The author showed how the first man to volunteer to marry a widow, Shreesh Chandra, a pandit in the Murshidabad Judge Court, escaped few days before his wedding to an eleven-year old widow Kalimati and returned to marry only from fear of losing his job and paying a hefty fine. Sunil shows cases of fraudulence as well. Many began to arrange fake widow marriages to collect the money promised. ${ }^{35}$ However, the novel shows genuine cases too. Initially most of these widows were from poor households who were getting married mainly to have a financial backup. The first instance of widow remarriage in a wealthy family in the novel was that of
Kushumkumari, daughter of Krishnanath Rae, who was married to Ganganarayan. The educated elites were accepting the reform and we see Nabinkumar even asking his wife to remarry if he dies.

Although widow remarriage began to gain popularity among different social classes of Bengal, it was not entirely an easy process. Most of these widows did not get the recognition of a legitimate bride in their new household. Sunil portrayed the lack of acceptances of such brides by showing how two cooks from Singha family left after the arrival of Kushumkumari and how Bimbabati never sent anything for the new bride. But the author drew most pathetic consequence of widow remarriage through the character of Subala who was once a student of Bethune School, no less. After the death of her first husband she was remarried to a rich zamindar family of Nilambar Mitra who married his sick son to a widow for an heir. After the death of his son, Nilambar Mitra sent his daughter-in-law to a brothel and Subala became a professional prostitute. Through the fate of Bindubashini, Sunil provided an example of the dire condition of widows in the nineteenth century. Bindubashini's misfortune continued as she was sent to the holy place, Varanasi, to distance her from Ganganarayan. It was a general practice to send widows into social oblivion in the name of religion. ${ }^{36}$ Varanasi, despite being a sacred and holy place, was not a safe place for the women who were sent there. We see a character in the novel describing how women were being bought and sold in Varanasi and some were even taken to Surat and shipped off to Arabia. Bindu was abducted in broad daylight by a goon named Devi Singh. She was tortured and abused to become a prostitute and even had a son. Here the author drew a very accurate scenario of male 
chauvinism of nineteenth century through the fact that she was announced dead for the whole world, without a single attempt of rescuing her as it would have been a matter of disgrace for her father Bidhusekhar. Thus a daughter of a pious Kulin Brahman family met a terrible end only because she was a widow. It is a fact that in the second half of the nineteenth century, a great number of prostitutes were the widows of Kulin Brahmins. ${ }^{37}$

Besides the tragic cases of prostitution in upper caste widows, professional prostitutes played a vital role in nineteenth century urban Bengal and they have widespread mention in the novel. There was a great difference between the two as the former was forced and the latter had the power of freedom. Kolkata in the nineteenth century had become a bustling cosmopolitan city and hence had several avenues of recreation of which prostitution or the concept of 'barbanita' was a main one. In 1853, Kolkata, with a population of about 400,000 people, supported 12,419 prostitutes, of whom more than 10,000 were Hindu and in 1867, although the city's population came down to some extent, the number of prostitutes rose to more than $30000 .^{38}$ Most of these professional prostitutes were rural women who were either tortured by their husbands or belonged to the lowest castes and poor families. ${ }^{39}$ Almost in every area of Kolkata there was a place for a brothel donated or established by a rich babu (gentleman). Sunil Gangopadhyay treats this demographic group with great importance throughout the novel which adds to the historical importance of this work. Areas like Bagbazar, Janbazar, Sonagachi, Bowbazar, Rambagan have been repeatedly mentioned by the author. Bowbazar being the main trading centre of Kolkata, it had many houses of ill repute as it was the fashion among elites to keep mistresses in Bowbazar. This was a huge profit making business and was flourishing immensely under rich patrons. Women from around Kolkata and also from farther areas used to come here to become prostitutes, knowingly or unknowingly. Many local women used to lie about their identity due to the demand of prostitutes from areas like Lucknow. Women actually from Lucknow were also commonly seen in the red light areas of Kolkata. In the novel, the author shows that after the arrival of the Nawab of Lucknow in Kolkata, female dancers and singers from Lucknow, Allahabad and Varanasi were coming to Kolkata to try their fortune. In many cases it was a hereditary business being passed on to generations of women in the recreation business. In many areas there were congested and low maintenance brothels where prostitutes of lower ranks lived in low rental houses and had random customers and low income. In big trading areas there were prostitutes in the inn for the convenience of the traders. Many random prostitutes were even found on the streets at night, dragging their potential customers. Some were so cheaply available that they charged two or four paisa. ${ }^{40}$ There was a prevalent social hierarchy among the prostitutes based on their beauty, calibre and demand among the elite class of nineteenth century Bengal. The famous prostitutes were very young, not beyond their early twenties. They had several famous elites like Ramkamal Singh, Jagmohan Sarkar as their clients and these rich clients even built or bought houses for their women. We find a description of Heeramoni's house from the novel where at night her house was flooded with light from the thirty lamps in her crystal chandeliers. A well-known folk poet Dashu Ray (1805-1857) remarked, "Satider anno joteyna, beshya der jaroa gohona" [the chaste wives cannot purchase food while the prostitutes wear 
expensive ornaments.] ${ }^{41}$ These high ranked prostitutes were generally under the control of one particular babu (gentleman) each who was her patron. These women were not only sex workers, rather, the high ranked ones were courtesans and artists well versed in the art of entertainment. Kamala Sundari was famous for her dancing skills and used to attain several functions of the babus including the Nabab of Lucknow himself who had great admiration for good art. On the other hand, Heeramoni had an extremely melodious voice. At one point, she left prostituting her body, became a professional singer and adopted a new name, Heera Bulbul, which was bestowed on her by an elite patron. She began to get invitations to sing at births, marriages, religious festivals from elite houses and could afford every luxury she cared for. These famous prostitutes had their own trainees as well. They kept two or three younger women and trained them to entertain guests in their place so that with advancing age their business would not stop. Along with the ranking of the prostitutes, the social class of the babus of Kolkata also depended on the prostitutes. A babu's glory and wealth was reflected through the prostitutes he kept. The author shows how, after Ramkamal's death, there was an indirect competition among the elites of the society to get a hand on Kamala Sundari as that would have been a matter of dignity to achieve a prostitute once kept by a rich zamindar. The author also shows how on the class one belonged to was reflected by the prostitutes he kept, as is shown through the character of Goopi, the goldsmith. Goopi who was once a petty worker was gradually transformed into a posh goldsmith with his own shop and workers. Gradually Goopi became Gopimohan Sarkar and his taste in prostitutes changed with his status. He kept on changing prostitutes every six months. His latest interest Rangi was snatched from another powerful elite
Kaliprasad Datta's clutch. This was a sign of power. While discussing about the fame of the prostitutes, the author also discusses the class of clients these prostitutes had. Along with the middle aged zamindars as the main clients and patrons of these women, the author also points out a new category of clients emerging for the prostitutes. With the growth of English education among the young generation, job holding middle class youths were migrating to Kolkata from small towns as most of the offices were located in Kolkata. Most of these young job holders had to leave their families at their native villages and lived in hostels. Educated elites were also among them. This new generation of clients was different from their predecessors and had different lifestyle and demands. ${ }^{42}$ In the novel we see Harish Mukherjee, a young famous news reporter was a regular client of Mulkchand's brothel. Though the prostitutes of good rank were admired by every class of clients and were flooded with money and jewels, they were one of the most oppressed classes of nineteenth century Bengal. Their glory and their power lived only in the dark. In broad daylight they were the untouchables and unrecognized by the same babus who regularly visited them at night. Their life in daylight was as ordinary as any other woman. To portray this side of the coin, Sunil showed day time's Heera Bulbul wearing a coarse saree, abusing her pupil, eating a mound of rice with her favorite greens and lentils sitting on the floor, legs stretched out before her.

The author also painted motherhood among these prostitutes by showing Heera Bulbul as a mother who never mentioned who the father of her son was. The author showed the struggle of a mother who demanded good education for her meritorious son but society did not let a prostitute's son have 
and education and a good life. Chandranath, Heeramoni's son was thrown out of Hindu College for being a prostitute's son. This gave him a mental scar for his entire life and he left his mother for good. Heera Bulbul and Chandranath's case had historical basis. Chandranath was admitted to Hindu College in 1853 and this triggered huge uproar among upper class Kolkata pupils. Sambad Pravakar, the Bengali language daily newspaper founded by Iswar Chandra Gupta, carried this news in its 11/11/1259 [1852], 16/11/1259 [1852], 7/4/1260 [1853] editions. ${ }^{43}$ The vivid descriptions of expensive and exclusive courtesans like Kamala Sundari and Heeramoni and many aspects of their life and character makes this novel an important source material for social historians.

Sunil Gangopaddhay though mostly portrayed the deplorable condition of the women during the period of "enlightenment", he also gave credit to the few women who made their own fortune and ruled. Thus we see the mention of female zamindars in the novel too. This paper shall end with the mention of such powerful female zamindars. Although women were theoretically unable to inherit property, there were other ways around the problem. A zamindari could be purchased for a woman as part of their 'stridhan' [dowry]. Women had the absolute right on the Stridhan ${ }^{44}$ which was passed down the female line. However, in exceptional cases women could inherit property. Possession of property gave them not only financial independence and power but also a chance to prove their capability of managing the property and that is shown in the novel through the character of female zamindar Rashmoni, the widowed daughter-in-law of the immensely wealthy Pretiram Marh of Janbazar who, without any male heir, displayed remarkable insight in managing her business and estate. Though she belonged to a poor Mahisya family and was illiterate, her knowledge of the world was phenomenal. She was very popular and was dignified by the title of Rani by her subjects. She was a name to reckon withone that commanded instant respect. Rani Rashmoni kept on multiplying her assets. The family business flourished under her guidance and a lot of property was added to the estate and she generously spent for the welfare of her people. Rani Rashmoni's devotion to all the gods of Hindu religion was unwavering. She led a very Spartan life and followed all the customs and rituals her religion demanded. She had a burning ambition to preserve Hinduism from the onslaughts of the Christians and Brahmos and spread the message of her glory throughout. The most interesting part of her character was her ways of dealing with the British on behalf of her tenants. When an Englishman complained against the noises her people made on an eve of Durga Puja festival and when the British tried to levy tax on dingee boats which were used by the fishermen of Rashmoni's zamindari to catch hilsha in Padma, we see Rani tackling both the situations single handedly and make the British surrender in both the cases. The author portrayed the strong character with the words, "The zamindarin of Zanbazar has rubbed the company's face in dirt."

Apart from the glory of the sixty-year-old female zamindar, the author has once again proved that he is unbiased when he shows her weakness as well. Despite being a very powerful ruler, Rani Rashmoni was not completely independent and needed the guidance of her son-in-law Mathur. Her dependence on Mathur was so high that she married her second daughter to Mathur after the death of her first daughter, Mathur's first wife. Nevertheless, to be fair to 
Rani Rashmoni, such events were socially accepted norms in the period under discussion. There is mention of another capable female zamindar in the novel, Anandamohini, mother of the zamindar of Manikganj, Purnachandra Rae. After her husband's death, she ran the zamindari with her able hands and did not leave the control even when her son grew up. Purnachandra received the zamindari only after her death.

\section{Concluding Remarks}

The novel Shei Shomoe serves as a reliable secondary source to know about the women of the so-called renaissance period in Bengal. That was the period when, for the first time, the private world of women was dragged out into the realm of public discourse. The author discusses a number of reform measures which were adopted in the nineteenth century. Men mostly started to educate their wives and came up with reform measures for women when they started to get western education and their circles began to include British and native elites. It was often a measure of gaining popularity in the society as the Woman's Question was a burning topic and also a sign of progress. Dulal Chandra in the novel started teaching his wife and keeping a servant for himself, when his monetary condition developed and both these facts were shown as a rise in his status. On the other hand, the novel shows that many elite intellectuals, in their evening gatherings, mocked the reform measures adopted for women. We see famous personalities like Jagmohan Sarkar at the beginning as a reformer and ending up as a fundamentalist. All in all, the reform measures for women were completely mens' matters and had least involvement of the women themselves. The women of the andarmahal, the widow suffering in Vanarasi, the posh prostitutes like Kamala and Heera, the powerful zamindar like Rashmoni-all these characters in the novel were not involved in the ongoing reform movement. Ironically, the reaction coming from the women towards these reform measures were mostly negative. The author shows how, in widow marriages, often the main obstacles came from the mother of grooms in fear of losing the religion and the education of women was blamed if the husband died. Thus the novel gives the alternate picture of how a large number of women in nineteenth century Bengal were not ready for the reforms brought about for them and how they were not a major party in the process. The novel takes us to another aspect of these reform movements that is the ongoing discrimination. We see one of the central characters Nabinkumar was charged for spending lavishly for widow reforms and not paying attention to the poverty of his tenants and also his concern for one person, Subala, an elite housewife who turned to prostitution after widowhood and not for thousands of women of poorer families stuck in the profession. This depicts the biased side of the Bengal Renaissance which the author has portrayed effortlessly.

Nevertheless, the novel gives the readers a hope, hope for a better world that was ushering in. We see Rani Rashmoni ruling gracefully and fighting the British with her intelligence, Durgamoni revolting viciously against her husband, Kushumkumari getting gladly accepted and respected when she came back to her parental home as a widow. These were signs of a new and changed world, the world of the twentieth century where women started to embrace the reforms in true form and began to step out of the andarmahal to create their own space in their own right. 


\section{References}

1. Allan. H. Pasco, "Literature as Historical Archive", New Literary History, Vol. 35, No. 3, The Johns Hopkins University Press, 2004, p. 373.

2. David Copf, "Bengal Renaissance", Banglapaedia, last modified17 February, 2015.

3. Hindu religious custom which compelled the widow to die with her husband's corpse in the funeral pyre.

4. Miriam Schneir, Feminism: The Essential Historical Writings, New York, 1972, p. XV.

5. Banglapaedia, last modified- 25th March, 2018.

6. Manmay Jafar, "Social Reforms in Colonial Bengal: Revisiting Vidyasagar", Philosophy and Progress, Dhaka, 2014, p. 113.

7. Ibid, p. 119.

8. Sumanta Banerjee, "Marginalization of Women's Popular Culture in Nineteenth Century Bengal', Recasting Women, Kumkum Sangari and Sudesh Veid (ed.), Kali for Women, India, 1989, p. 127.

9. The head woman of a joint family who controls the indoor management of the house.

10. According to Banglapedia, Young Bengal was a sociointellectual label that was given to the students of Hindu College who followed their teacher Henry Louis Vivian Derozio, a free thinker and rationalist.

11. Sumanta Banerjee, op. cit., p. 162.

12. James Kerr, Domestic Life, Character, and Customs of the Natives of India, W.H Allen \& Co, London, 1865, p. 76.

13. S .C Bose, The Hindoos As They Are, Thacker, Spink and Co, London, 1883, pp. 2-3.
14. "Kaparwali", Bengali Monthly Newspaper Prabashi, 27th edition, Bengali year 1334 (Pausha), p. 316.

15. Sumanta Banerjee, op.cit., p. 129.

16. Zenana means the part of the house for the seclusion of womem. It has been used as a synonym to andarmahal.

17. Meredith Borthwick, The Changing Role of Women in Bengal 1849-1905, Princeton University Press, New Jersey, 1984, p. 9.

18. Ibid, p. 13.

19. Jasodhara Baghchi, "Socialising the Girl Child in Colonial Bengal", Economic and Political Weekly, 1993, p. 2214.

20. H. Beverley, Census of Bengal (1872,) Report, Bengal Secretariat Press, Kolkata, 1872, p. 58.

21. Cremetion is a ceremony (Shraddha) in Hindu custom where a son has to put fire in the mouth of his dead parent.

22. Jervoise A Baines, Census of India (1891), Report, Vol. 1, Eyre and Spottiswoode, London, 1893, p. 212.

23. According to The British Library, the Kulin Brahmans were a branch of the Hindu priestly class in Bengal whose social organisation included a well-established polygamy system, which was often turned into profession by the kulins. There was social acceptance to his living entirely off his year-round visits to in-laws houses where his many wives lived permanently.

24. George W Johnson, Stranger in India: or, Three years in Calcutta, Vol. 1, Henry Colburn Publisher, London, 1843, p. 233.

25. L.S.S O'Malley, Indian Caste Customs, Cambridge University Press, London, 1996, p. 10.

26. A Kulin who married a non-Kulin.

27. Asha Islam Nayeem, "Emancipation of Women through Education", The Journal of the Asiatic Society of Bangladesh, Dhaka, 2015, p. 3824. 
28. Meredith Borthwick, op.cit., p. 61.

29. Grihakatha, Masik Patrika and Krishna Mohan Banerjea's answers to questions on female education in the Calcutta Christian Observer, March 1840, cited in Meredith Borthwick, p. 61.

30. Ibid

31. Census of British India (1881), op.cit., p. 95.

32. B. Kumar Chakravarty, Loka Sanskriti: Nana Prasanga, Book Trust Kolkata, Kolkata, 1981, p. 20-21.

33. It is the conch shell bangle that Hindu women wear as a symbol of their status as a married woman.

34. Sirajul Islam (ed), History of Bangladesh (1704-1971), Vol. 3, Asiatic Society of Bangladesh, Dhaka, 1992, p. 733.

35. Binay Ghosh, Shamoyikpatre Banglar Shamajchitra, Vol. 3, Bikhhan, 1964, p. 377.

36. Swati Ghosh, "Bengali Widows of Varanasi", Economic and Political Weekly, 2000, p. 1151.

37. "Kulin Polygamy", The Calcutta Review, Vol. XVII, 1863, p. 142.

38. Report of Chief Magistrate of Calcutta and Calcutta Municipal Corporation Health Report, quoted in U. Chakravarti, Condition of Bengali Women around the Second Half of the Nineteenth Century, (Published by author in Kolkata. 1963), p. 97.

39. Samvad Bhaskar (1 May 1851), cited in Sumanta Banerjee's Dangerous Outcast: The Prostitute in Nineteenth Century Bengal, p. 85.

40. Durgacharan Ray, Debganer Martye Agaman, Dey’s Publishing, Kolkata, 1984, p. 558.

41. Haripada Chakravarty, Dasharathi O Tanhar Panchali, Kolkata, 1960, p. 375.
42. Sumanta Banerjee, Dangerous Outcast: The Prostitute in Nineteenth Century Bengal, Seagull Books, London, 1998, p. 101.

43. Bdyabinod Mitra and Sukhirkumar, Hughli Jelar Itihash, Shishir Publishing House, Kolkata, 1948, p. 919.

44. Prafulla Chandra Ray, Life and Experiences of a Bengali Chemist, Chuckervertty, Chatterjee and Co. Ltd, 1932, p. 46.

\section{Acknowledgement}

I am very grateful to Professor Dr. Asha Islam Nayeem for reading several versions of this article, for her valuable comments and for sharing insights which have helped me to sharpen the research work. 